\title{
PENDIDIKAN AGAMA HINDU DALAM PEMENTASAN TARI BARONG KETET UNTUK PERTUNJUKAN PARIWISATA DI BANJAR DENJALAN BATUBULAN
}

\author{
Oleh : \\ I Nyoman Alit Supandi
}

\begin{abstract}
ABSTRAK
Tari Barong tidak termasuk tari wali, tetapi tidak semua barong tidak temasuk tari wali, Salah satu tari Barong yang secara kontinyu dipertontonkan adalah tari barong ketet di banjar denjalan desa Batubulan untuk pertunjukkan pariwisata, tari ini memiliki kesenian yang sangat menarik, hal ini akan mendukung perkembangan pariwisata. Yudabakti dan Watra 2007:25 Seni atau estetika yang jangkaunnya tidak terbatas pada suatu daerah tertentu saja, akan tetapi berlaku secara mendunia dan universal. Bahasanya menjangkau termasuk wilayah Bali yang sudah terkenal tentang seninya. Salah satu wujud kesenian yang dipertunjukkan sebagai hiburan pariwisata yaitu tari barong ketet. Kenapa tari Barong Ketet ini di tulis Karena tari Barong Ketet ini sudah terkenal, melihat dari segi ceritra mengandung unsur kebaikan dan keburukan. Didalam jaman gelobalisasi ini, orang lebih cenderung mengejar kemajuan tampa melihat dampak negatifnya. Disamping tari Barong Ketet ini memiliki unsur ruwa bineda juga terkandung nilai pendidikan estetis, religiusnya, dan sosial masyarakat. Sehubungan dengan hal tersebut di atas, maka pertunjukkan tari Barong Ketet ini sangat menarik untuk ditulis. Adapun hasil penulisan ini adalah sebagai berikut 1. prosesi pementasan tari Barong Ketet terlebih dahulu dilakukan persiapan untuk pementasan, ada yang mengatur dibidang gambelan, dekorasi, tiket, peralatan dan pakian. 2. Nilai yang terkandung didalam pementasan barong ketet yaiu nilai pendidikan estetis religius dan sosial masyarakat. Estetisnya terletak kepada periasan barong dan kuubnya barong, sedangkan nilai religiusnya terdapat pada saat pementasan harus mempersembahkan sesajen dari pada itu setiap pementasan sebaiknya mempersembahkan sesajen, guna untuk mendapatkan keharmonisan. sedangkan nilai sosial masyarakat terdapat pada aktipitas pelaksanaan pementasan terjalin kerjasama yang sangat baik, karena seke barong menyadari bahwa manusia adalah sebagai mahluk yang sosial, dan memiliki pedoman tatwa masi sehingga semuanya adalah sama dan tidak ada yang membedakan satu antara yang lainnya.
\end{abstract}

\section{Kata Kunci : Pendidikan Agama, Pementasan, Tari Barong Ketet}

\section{ABSTRACT}

Barong Dance is not included to a sacred dance, but not all barong dance is not include in sacred dance. One of the Barong dances that is continuously performed is the Barong Ketet dance in Banjar Denjalan Batubulan for the tourist attraction. This dance shows a very interesting art, it will support the tourism development. Yudabakti and Watra 2007: 25 state that art or aesthetic has a non-limited area, but applicable worldwide and universal. Bali itself has been well known about its art. One form of the art that is performed as entertainment or tourist attraction is Barong Ketet dance. Barong Ketetis already well known, in terms of the story, it contains elements of good and evil. In the globalization era people are more likely to pursue progress without seeing the negative impacts. Besides, this Barong Ketet dance also contained elements of Ruwa Bhineda, aesthetic, education, religious, and social values. Therefore,Barong

Pendidikan Agama Hindu Dalam Pementasan Tari Barong Ketet Untuk

Pertunjukan Pariwisata Di Banjar Denjalan Batubulan 
Ketetdance performance is very interesting to be studied. The results of this writing describes; 1. procession of Barong Ketet dance performance, including the preparations for the stage, gambelan, decorations, ticket, equipment and clothes. 2. The value contained in the staging of Barong Ketet namely, aesthetic, religious, education and social values. The aesthetic is shown from the grooming of the barong and the kuub, while religious values is presented by the community who always present an offering at every staging in order to get the harmony, while the social values can be seen through the cooperation of the society before barong dance performance, where people admit and realizes that man is a social creature who have Tatwam asi guidelines so everything is the same and there is nothing to distinguish one another.

\section{Keywords: Religion, Staging, Barong Ketet Dance}

\section{PENDAHULUAN}

Dibia 2011:151 Seperti telah diketahui bahwa pulau Dewata merupakan daerah pariwisata. Masing-masing Kabupaten bahkan setiap desa serta Banjar memiliki warisan kesenian tersendiri sebagai aset pariwisata bagi daerahnya. Hal tersebut dilakukan karena alasan-alasan tertentu seperti misalnya : tempatnya yang strategis, lancarnya hubungan transportasi, kualitas keseniannya. Dalam upaya pengembangan pembangunan pariwisata berbagai usaha telah dilakukan oleh pemerintah maupun swasta seperti penyediaan fasilitas-fasilitas pariwisata. Berbicara masalah pariwisata maka perhatian tertuju kepada pulau Bali karena daerah ini merupakan tujuan wisata yang paling dominan di Indonesia. Hal ini disebabkan oleh banyaknya memiliki peninggalan-peninggalan sejarah yang bernilai tinggi, serta pemandangan alamnya yang mempesona, keramahtamahan penduduknya, dan warisan seni budaya yang beraneka ragam, salah satunya adalah kesenian tari Barong Ketet. Dibia 2000;11 Tari Barong tidak termasuk tari wali. Sebagaimana telah banyak dikemukakan oleh para hali bahwa didalam pertunjukan tari Barong melibatkan benda-benda sakral yang amat dikramatkan oleh warga masyarakat pendukungnya. Sedangkan kalau tari Barong Ketet yang ada di desa Batubulan lebih mengkhusus di Banjar
Denjalan, ini termasuk tari balih-balihan dan secara langsung memiliki nilai yang religius. Pada umumnya tari Barong Ketet ini dipertunjukkan untuk menghibur wisatawan baik yang berasal dari manca negara maupun wisatawan domestik yang datang ke pulau Bali untuk berrekreasi. Salah satu tari Barong yang secara kontinyu dipertontonkan untuk pertunjukkan pariwisata, Mengingat daya tarik tari Barong tersebut baik terhadap wisatawan domestik maupun wisatawan manca negara, maka perlu dilakukan bimbingan terhadap tari Barong tersebut untuk meningkatkan mutu pertunjukkan agar daya tarik dari kesenian ini tidak memudar.

Sehubungan dengan hal tersebut diatas, Barong Ketet ini dipentaskan di Banjar Denjalan Desa Batubulan, memiliki kesenian yang sangat menarik, hal ini akan mendukung perkembangan pariwisata. Salah satu wujud kesenian yang dipertunjukkan sebagai hiburan pariwisata. Kenapa tari Barong Ketet ini di tulis Karena tari Barong Ketet ini sudah terkenal, melihat dari segi ceritra mengandung unsur kebaikan dan keburukan bisa juga disebut dengan Ruwe bineda, kebaikan inilah patut kita lakukan tidak adalain untuk mencapai keharmonisan atau patuh dengan ajaran Agama. Didalam jaman gelobalisasi ini, orang lebih cenderung mengejar kemajuan tampa melihat dampak negatifnya. Disamping itu kita ingin mengetahwi bagaimana prosesi 
pementasan tari Barong Ketet. dan nilai apa yang terdapat di dalam pementasan. Sehubungan dengan hal tersebut di atas, maka pertunjukkan tari Barong Ketet ini sangat menarik untuk dijanikan tulisan dengan bentuk jurnal.

\section{PEMBAHASAN}

Bertitik tolak dari latar belakang masalah di atas, maka dapat dirumuskan permasalahnya sebagai berikut:

\section{Prosesi pementasan tari Barong Ketet untuk pertunjukkan pariwisata}

terlebih dahulu dilakukan dekorasi di pagi harinya, kemudian membuka sarung gambelan, menyiapkan panggul gambelan, membersihkan di sekitar pementasan Barong, mempersiapkan peralatan berhias bagi penari disamping itu supaya penari sangat mudah untuk mengambil peralatannya yang sudah disediaka. sehabis mempersiapkan pakian juga mempersiapkan tiket untuk orang yang akan menonton Barong. Setelah itu pemangku atau orang suci ngaturan piuning supaya didalam pementasan Barong berjalan dengan lancar atau apa yang telah kita harapkan. Selesai pemangku atau orang suci ngaturan piuning seke Barong baik itu penari, penabuh, tukang penjual tiket dan penyambut tamu mempersiapkan diri sesuai dengan tugasnya, kemudian setelah waktu menujukkan 09.15 wita barulah di mulai pertunjukan Barong yang diawali dengan tabuh pembukaan yang disebut dengan tabuh Bebarongan, sambil menunggu kehadiran tamu yang menonton pertunjukan Barong. Setelah menunjukkan pukul 09.30 wita barulah pertunjukan inti tari Barong dimuli. Dibia 2012:151 Mengatakan bahwa perubahan dan pembaharuan seni pertunjukan wisatawan di Bali dewasa ini ditandai masih tetap dominannya bentukbentuk seni pertunjukan wisata produk lama yang masih merajai di panggung hiburan wisata di berbagai tempat di bali, seperti di banjar denjalan pementasan tari barong ketet masih tetap eksis. Babak Pertama yaitu, Dua orang penari muncul dan mereka adalah pengikut-pengikut dari rangda sedang mencari pengikut dewi Kunti yang sedang dalam perjalanan untuk menemui patihnya. Babak Kedua Pengikut-pengikut dewi Kunti tiba. Salah satu dari pengikut Rangda berubah rupa menjadi setan (Semacam Rangda) dan memasukkan roh jahat kepada pengikut dewi Kunti yang menyebabkan mereka bisa menjadi marah. Kedua menemui patih dan bersama-sama menghadap Kunti. Babak Ketiga Muncullah dewi Kunti dan anaknya Sadewa dan dewi Kunti berjanji kepada rangda untuk menyerahkan Sadewa sebagai korban. Sebenarnya dewi Kunti tidak sampai hati mengorbankan anaknya Sadewa kepada rangda tetapi setan (semacam Rangda) memasuki roh jahat kepadanya yang menyebabkan Dewi Kunti bisa menjadi marah dan tetap berniat mengorbankan anaknya kepada patihnya untuk membuang Sadewa kedalam hutan dan patih inipun tidak luput dari kemasukkan roh jahat oleh setan itu sehingga sang patih dengan tampa perasan kemanusiaan, mengiring Sadewa kedalam hutan dan mengikatnya di muka istana sang Rangda. Babak ke Empat Turunlah Dewa Siwa dan memberikan keabadian hidup kepada Sadewa dan kejadian ini tidak diketahwi oleh Rangda. Kemudian datanglah Rangda untuk mengoyak-ngoyak dan membunuh Sadewa tetapi tidak dapat dibunuhnya karena kekebalan yang dianugrahkan oleh Dewa Siwa. Rangda menyerah kepada Sadewa dan memohon untuk diselamatkan agar dengan demikian dia bisa masuk sorga. Permintaan itu dipenuhi oleh Sadewa. Sang Rangda mendapat Sorga. Babak Kelima. Kalika salah pengikut Rangda menghadap kepada Sadewa untuk diselamatkan juga tetapi ditolak oleh Sadewa. Penolakan ini menimbulkan perkelahian dan Kalika berubah rupa menjadi, "Babi hutan" dan didalam pertarungan antara Sadewa melawan Babi hutan Sadewa mendapatkan kemenangan. Kemudian Kalika (Babi hutan) 
ini berubah menjadi "Burung" tetapi tetap dikalahkan. Dan akhirnya Kalika (Burung) berubah rupa lagi menjadi rangda oleh karena saktinya Rangda ini maka Sadewa tidak dapat membunuhnya dan akhirnya Sadewa berubah rupa menjadi Barong karena sama saktinya maka pertarungan antara Barong melawan Rangda ini tidak ada yang menang dan kalah dengan demikian pertarungan dan perkelahian ini berlangsung terus abadi "Kebajikan" melawan "Kebatilan". Kemudian muncullah pengikut-pengikut Barong masing-masing dengan kerisnya yang hendak menolong Barong dalam pertarungan melawan Rangda. Mereka ini semuanya tidak berasil melumpuhkan kesaktian sang Rangda.

Berdasarkan pembabakan-pembabakan yang ada banyak hal yang dikembangkan didalam pementasan tari Barong, ini terlihat pada brosur Barong (Tek Ceritra) dibandingkan dengan kenyataan dalam pementasan. Ini terlihat pada gerak-gerik penasar ketemu dengan celuluk demikian juga pada saat menyembelih babi yang dapat mengundang tawa para penonton dengan gerak gerik penari yang lucu. Dapat dipetik dari penjelasan diatas bahwa Kebaikan akan menang melawan kejahatan. Kalau kita lihat brosur Barong (Tek Ceritra), Tarian Barong menggambarkan pertarungan antara "Kebajikan" Barong adalah binatang purbakala melukiskan "kebajikan" dan Rangda binatang purbakala yang maha dahsyat menggambarkan "Kebatilan". Kebaikan inilah yang patut dijanika contoh atau pedoman dalam melaksanakan suatu aktifitas sehingga mendapakan jalan kedamian keharmonisn kita bersama.

\section{Nilai pendidikan estetis dalam pementasan tari barong ketet}

Sebelum menjabarkan tentang nilai pendidikan estetis, terlebih dahulu penulis menjelaskan apa itu nilai pendidikan. Nilai adalah sesuatu yang menyebabkan hal itu pantas dikejar oleh manusia. Menurut Scheler (dalam Suparno, 2002:77) dinyatakan bahwa nilai merupakan suatu "kenyataan" yang tersembunyi di balik kenyataan-kenyataan lain. Sedangkan Pendidikan adalah suatu proses pengubahan sikap dan prilaku seseorang atau kelompok orang dalam usaha mendewasakan manusia melaui pengajaran dan pelatihan, Wahyudin, dkk, (2008:314) menyatakan bahwa pendidikan adalah semua pengalaman hidup yang berlangsung didalam lingkungan keluarga, masyarakat, sekolah yang berhubungan erat, saling melengkapi dan berpengaruh positif bagi perkembangan individu. jadi Nilai pendidikan adalah suatu proses pengubahan sikap dan prilaku seseorang atau kelompok orang untuk dapat memilah perbuatan yang baik dan perbuatan yang buruk dalam proses mendewasakan manusia melalui cara pengendalian diri, dan kesadaran untuk berbuat, berpikir dan berkata yang lebih baik. Berdasarkan uraian di atas, bahwa nilai Pendidikan sangat penting bagi seseorang dalam proses mendewasakan manusia baik dari cara berpikir, berkata dan berbuat, serta dapat memberikan pengalaman hidup, baik dalam lingkungan keluarga, masyarakat, yang berhubungan erat saling melengkapi dan berpengaruh positif bagi perkembangan individu, sehingga pendidikan tidak hanya diperoleh disekolah, tetapi dalam keluarga, tempat suci dan masyarakat. Seperti pada penulisan ini, bahwa nilai pendidikan yang terkandung pada Barong ketet yaitu nilai pendidikan estetis, Nilai estetis selain terdiri dari keindahan sebagai nilai yang positif kini dianggap pula meliputi nilai yang negatif. Hal yang menunjukkan nilai negatif itu ialah kejelekan (ugliness). Kejelekan tidaklah berarti kosongnya atau kurangnya ciri-ciri yang membuat sesuatu benda disebut indah, melainkan menunjuk pada ciri-ciri yang sangat bertentangan sepenuhnya dengan kualitas yang indah itu. Dalam kecenderungan seni dewasa ini, keindahan tidak lagi merupakan tujuan yang paling penting dari seni. Sebagian seniman menganggap lebih penting menggoncangkan 
publik daripada menyenangkan orang engan karya seni mereka. Goncangan perasaan dan kejutan batin itu dapat terjadi, dengan melalui keindahan maupun kejelekan. Oleh karena itu, kini keindahan dan kejelekan sebagai nilai estetis yang positif dan yang negatif menjadi sasaran. Estetika berasal dari bahasa Yunani yaitu kata "Aesthetis" yang berarti perasaan atau sensitivitas. Keindahan sangat erat hubungannya dengan selera dan perasaan, akan tetapi saat ini diartikan sebagai segala pemikiran filosofis tentang "seni". Aktivitas estetis masyarakat Bali pada mulanya berfungsi untuk memenuhi kebutuhannya dalam upaya memelihara kesejahteraan hubungan antara manusia dengan tuhannya, manusia dengan lingkungan hidupnya, dan manusia dengan sesamanya sehingga terwujudanya kesejahteraan yang seimbang antara material dan spriritual yang dikenal dengan istilah Tri Hita Karana (Geriya. 1999:93) atas dasar konsep tersebut muncullah kreativitasnya di bidang kesenian sebagai pendukung upacara seperti seni ukir diwujudkan dalam pembuatan patungpatung, sebagai sesembahan, seni suara yang diwujudkan dalam tembang-tembang yang disebut dengan kekawin, seni tabuh pengiring upacara. Dibia 2003:93 kesenian apapun bentuknya pada dasarnya merupakan hasil dari kreatifitas. Kesenian tidak akan bisa dilepaskan dari ikatan nilai-nilai luhur budaya, termasuk estetika yang hidup dan berkembang di lingkungan masyarakat tempat asal seniman yang bersangkutan. Kesenian Bali yang merupakan hasil kreatifitas seniman yang berbudaya Bali sangat erat dengan estetis yang dijiwai oleh nilai-nilai budaya yang diikat oleh agama. Dibia 2012:7 mengatakan bahwa seni tari Bali, sebagai bagian dari warisan budaya hindu, menyatukan gerak- gerak yang bersifat sakral dan teatrikal. Didalamnya juga berbaur eksprsi budaya individual dan komonal dari masyarakat setempat. Nilai estetis pada umumnya kini diartikan sebagai kemampuan dari suatu benda untuk menimbulkan suatu pengalaman estetis. Sedangkan kalau kita lihat bentuk Barong ketet sangat estetis. Mengawali proses pembuatan Barong sangat menjadi pertimbangan yang matang bagi para sangging atau (Tukang) sehingga nantinya setelah terwujud Barong itu, dapat di mainkan leluasa atau dimainkan dengan nyaman dan bebas oleh para seniman atau pemain Barong yang juga disebut juru bapang Barong. Dari hal tersebut diatas agar juru bapang dapat berkreasi dan berinovasi dengan bebas, maka pembuatan Barong Ketet itu melampaui beberapa proses yaitu:

1. Pembuatan kerangka Barong, pembuatan kerangka yang terdiri dari ruang kepala, badan dan ekor disesuaikan dengan bentuk binatang itu yang terdiri dari ruang kepala, badan dan ekor, sedangkan kaki Barong adalah kaki para pemain maka Barong itu dibuat dua ruang, penghubung ke dua ruang itu dibuat secara elastis atau lentur sehingga pada saat digerakkan kelihatan indah.

2. Pembuatan bulu Barong, pembuatan bulu yang dibuat dari prasok diikat dengan tali untuk menutup kerangka Barong sehingga kelihatannya menyatu dua ruang menjadi satu, sesuai bentuknya yang diinginkan.

3. Pembuatan hiasan diambil dari bentuk plora dan faona sehingga ukir-ukiran dalam hiasan badan Barong menjadi indah disamping dari segi bentuk ruang ukir-ukiran seperti adanya yang disebut: bapang, Angkep pala, kuwer, garuda mungkur, ampok-ampok, sekar taji dan lain sebagainya.

4. Pembuatan tapel, pembuatan tapel atau kepala Barong dibuat sedemikian rupa, menurut nama Barong itu sendiri, saat Barong bangkal dibuatlah kepala babi, Barong Ketet dibuatlah kepala harimau atau macan demikian pula Barong-Barong yang lainnya. Sedangkan kombinasi warna dikombinasikan oleh sangging dengan unsur-unsur yang telah ditentukan sehingga kelihatan hidup dan indah. 
Berdasarkan proses pembuatan Barong, nilai estetis sangat diperhitungkan oleh para sangging atau pembuat Barong, dilain tempat ada juga menyebut undagi pada dasarnya semua sebutan itu adalah sama. Pelaksanaan pembuatan bentuk-bentuk yang indah hasil karya seni suatu khasanah bangsa.

Barong Ketet adalah dua ruang yang dapat di gerakkan dengan elastis beserta bulu dan hiasan-hiasan yang lainnya mengandung unsur-unsur alam yang diapresiasikan dalam bentuk ukiran-ukiran dan ruang yang telah disesuaikan dengan fungsi dan letak yang telah disesuaikan, sehingga keindahan bentuk Barong ketet memiliki suatu karisma estetis apalagi dimainkan atau ditarikan diiringi dengan tetabuhan atau gambelan, dan ini sangat kompak nilai estetisnya. Disamping itu nilai estetis yang terdapat pada pepayasannya diantaranya adalah sekar taji, petites, jenggot, kendon atu mahkota, angkeb pala, kuer, selendang, lelontekan, pepudakan, , tutup pantad barong, keleneng gongsiang, ikuh, tetulangan keranjang didalam kerangka barong ini juga sangat estetis terdapat pada ulat-ulatannya disamping itu ada bunga yang berwarna merah, bulu jaran, dan ronronan, dan adapula keindahannya terdapat pada tukang bapang perlengkapannya yaitu jalernya berwarna-warni, kamen bulat ginting, ada kampuhnya, setiwel yang terdapat pada kaki, bulu dan grongsiang. Kalau dipandang keseluruhan Barong terdapat estetis pada koub antara kepala, badan dan ekor seimbang, dan tidak terlepas dari sikut atau uger-uger.

Menurut Triguna, 2000:47 menyatakan bahwa estetika merupakan kata lain dari seni, dalam konsep estetika Hindu Bali khususnya terdapat di dalam konsep Tri Wesesa yaitu tiga konsep ajaran antara lain Satyam (kebenaran), Siwam (kesucian), Sundaram (keindahan). Ketiga konsep ini merupakan satu kesatuan untuk membentuk tempat agar dapat dikatakan suci. Nilai estetika juga berarti nilai pendidikan seni dan budaya. Estetika secara kesimpulan adalah segala sesuatu yang membuat kita kagum, takjub dan didalamnya terdapat makna kebaikan, kebenaran dan menyenangkan antara mengamat dan objek yang diamatinya. Berdasarkan penjelasan tersebut memang benar terdapat estetis dalam barong ketet.

\section{Nilai Pendidikan Religius didalam pementasan tari Barong Ketet}

Setiap manusia sadar bahwa selain dunia yang fana ini, ada suatu alam dunia yang tak tampak olehnya dan berada di luar batas akalnya, yaitu supernatural, atau dunia alam gaib, tetapi manusia di sini mempunyai suatu kepercayaan adanya Tuhan. kepercayaan di jalankan dengan cara-cara beragama (agama formal) maupun melalui cara-cara kepercayaan lain di luar agama (formal) tetapi intinya percaya kepada alam transenden dan tidak menolak Tuhan seperti yang dianut paham komunis Artodi; 2004:81. Teori Tylor mengenai asal-mula dan inti dari suatu unsur universal seperti religi atau agama, tegasnya mengapa manusia percaya kepada suatu kekuatan yang dianggapnya lebih tinggi dari dirinya, dan mengapa manusia melakukan berbagai macam cara untuk mencari hubungan dengan kekuatan-kekuatan tadi, telah menjadi obyek perhatian para ahli. Ada bermacammacam pendiri dan teori yang berbeda-beda mengenai masalah tersebut, dan diantaranya teori-teori yang penting menyebutkan bahwa prilaku manusia yang bersifat religi itu terjadi karena: (1). Manusia mulai sadar akan adanya konsep roh; (2). Manusia mengakui adanya berbagai gejala yang tak dapat dijelaskan dengan akal; (3). Keinginan manusia untuk menghadapi berbagai krisis yang senantiasa dialami manusia dalam hidupnya ; (4). Kejadian-kejadian luar biasa yang dialami manusia di alam sekelilingnya; (5). Adanya getaran (yaitu emosi) berupa rasa kesatuan yang timbul dalam jiwa manusia sebagai warga dari masyarakatnya; (6). Manusia menerima suatu firman dari Tuhan. (Koentjaraningrat, 2002:194-195). 
Menurut teori Evolusi Religi manusia: (1). Animesme bentuk religi yang tertua; (2). Adanya kekuatan yang memggerakkan alam dewa-dewa; (3). Tata kenegaraan-susunan dewa-dewa sehingga ada raja tertinggi para dewa; (4). Dewa-dewa itu penjelmaan satu dewa sehingga menimbulkan paham monoteisme sebagai tingkat terakhir evolusi religi manusia Duija, 2006:28. Dalam teori religi makna religi yang perlu diketahui peneliti budaya. Pertama, religi adalah agama yang berdasarkan wahyu Tuhan. Karena itu, religi tidak bisa dijangkau oleh daya manusia dan apabila dicari kebenarannya. Batasan semacam ini pun sebenarnya tidak keliru, tetapi menarik bagi peneliti budaya bukan pada hal tersebut, melainkan religi dalam pengertian luas. Kedua, religi dalam artian luas berarti meliputi variasi pemujaan, spiritual, dan sejumlah praktek hidup yang telah bercampur dengan budaya, misalkan saja tentang magi, pemujaan pada binatang, pemujaan pada benda, kepercayaan atau takhayul dan sebagainya (Endraswara, 2006 : 162). Religus yang terdapat pada tari borong ketet adalah sebelum memulai pementasan terlebih dahulu mengaturkan piuning ke surya, gong dan pelinggih gong, sarananya adalah pejati sedangkan sarana kepada pelinggih gong adalah petangi. Sehabis memberikan sesajen dilaksanakanlah ngaturan banten kepada Barong sakral, ini disebut dengan mendak, upakaranya pada saat mendak terdiri dari pesucian, rantasan, cecepan penastan, canang gental, canang rebong, dan tabuhan. Barong sakral ini Bersetana di gedong, tujuannya supaya didalam pementasan mencapai suatu hubungan yang harmonis. Setelah memberikan sesajin kepada Barong yang sakral dilanjutkan ngaturan piuning ring pesimpangan tujuannya disini supaya didalam pementasan penari dan penabuh supaya selamat didalam pertunjukan, kemudian dilanjutkan ngaturan piuning di tugu pengijeng, tugu pengijeng ini adalah bertugas sebagai menjaga, tanggung jawab, penguasa karang, penolak bala, dulunya pernah kejadian anggota penari terluka kena keris dan berdarah, kemudian ditanyakan kepada orang yang tau tentang apa yang terjadi pada saat penari itu menari ternyata harus mengaturkan sesajen pada saat pementasan, maka dari itu kepercayaan masyarakat apabila melaksanakan pementasan barong tidak berani tidak mengaturan piuning di tugu pangijeng. Kemudian dilanjutkan ngaturan piuning di barong yang akan di pentasan, sehabis itu dilanjutkan ke tempat pertunjukan (kalangan), kemudian barulah ngaturan piuning di pesimpangan ratu dalam. sebelum Barong dan rangda dipentaskan terlebih dahulu pemangku mengaturkan sesajen, sehingga pada saat waktu pementasan barong dan rangda langsung bisa ditarikan. Disamping itu, tujuan untuk memberikan aura religius dan mengundang taksu. sebelum melakukan pementasan terlebih dahulu dilaksanakanlah ngaturan banten kalangan, ada beberapa sarana terdiri dari peras ajengan, lekesan, segehan Sembilan tanding segehan ini diaturkan ke Dewata Nawa Sanga. Setiap pementasan alangkah baiknya melaksanakan proses yang telah dipaparkan, inilah religius yang terdapat didalam pementasan Barong.

Agama betul-betul menjadi motivasi di dalam berbuat suatu kebajikan. Sehingga agama hendaknya dipakai sebagai suatu landasan hidup karena dapat memberikan ketentraman dan membebaskan manusia dari kegelapan dalam hidupnya. Apabila manusia mematuhi ajaran agama yang dianut oleh masing-masing umatnya. Percaya dengan adanya Tuhan atau Sang Hyang Widhi ini merupakan keyakinan yang tertuang di dalam pustaka suci Veda. "Ekam Eva Adityam Brahman" artinya, hanya ada satu Ida Sang Hyang Widhi Wasa atau Brahman tidak ada yang kedua. "Eko Narayana $\mathrm{Na}$ Dwityaasti Kascit" artinya, hanya satu Ida Sang Hyang Widhi Wasa sama sekali tidak ada duanya. Dalam sistem ajaran Hindu sradha mempunyai fungsi dan kedudukan sebagai kerangka dharma, kerangka bentuk 
isi daripada agama. Sradha sebagai alat atau sarana dalam mengatur manusia menuju kepada Ida Sang Hyang Widhi Wasa. Pengertian ini diungkapkan dalam kitab suci Yajurveda XIX.77, sebagai berikut :

\section{Drstvā rupe vyākarot satyānrte prajāpatih, asraddhāmanrte- 'dadhācchaddhām satye prajāpatih, rtena satyamindriyam vipānam sukramandhasa, indrasyendra-yamidam payo'mrtam madhu.}

Terjemahan :

Dengan melihat dua bentuk Prajapati memberikan kebenaran dan bentuk tipuan yang berbentuk. Prajapati menandai kurangnya kepercayaan pada tipuan, kepercayaan kepada kebenaran dan keadilan, (Griffith, 2005: 394).

Berbagai sudut pandang religius barong ketet dengan kajian pustaka ini sangat berkaitan, bahwa religius khususnya didalam pementasan barong ketet, kalau kita bahas tentang Pratyaksa Pramana kita melihat kenyataan secara langsung, seperti pada saat penari itu terluka kena keris, kemudian Anumana Pramana ini pertimbangan yang logis pada saat terjadi feno mena ini melakukan ngaturan piuning, sesajen di tugu pangijeng, kemudian Agama Pramana, yaitu mengetahui melalui orang yang wajar dipercaya, sehingga kita melaksanakan aktifitas yang di percayai sehingga dijalanni sampai saat ini. Inilah nilai religius yang terdapat pada pertunjukan tari Barong di Banjar Denjalan Batubulan.

\section{Nilai Pendidikan Sosial Masyarakat pada Pementasan Barong}

Muhammad 2005:5 menyatakan, bahwa manusia adalah makhluk sosial (zoon politicon) artinya manusia sebagai individu tidak akan mampu hidup sendiri dan berkembang sempurna tanpa hidup bersama dengan individu manusia yang lain. Dengan kata lain, manusia harus hidup bermasyarakat. Hidup bermasyarakat artinya saling berhubungan dan berinteraksi satu sama lain dalam kelompoknya dan juga dengan individu diluar kelompoknya, guna memperjuangkan dan memenuhi kepentingannya. Manusia memiliki unsur akal ( ratio ), rasa (sense), dan karsa ( wiil, wish), sehingga manusia pula disebut makhluk budaya. Seperti kita lihat dalam pementasan tari barong ketet memiliki nilai pendidikan sosial, dan mempunyai suatu hubungan yang sangat erat baik pendidikan maupun masyarakat. Karena semua ini memegang peranan yang sangat penting didalam pementasan tari Barong ketet. Sosial masyarakat ini terletak pada persiapan sebelum pementasan dimulai, baik itu antara penabuh, penari dan pendukung di dalam pementasan tari barong ketet, sehingga tari barong ketet ini bisa berjalan sesusi dengan pelaksanaan yang telah diharapkan, tanpa adanya sosial masyarakat pementasan ini pasti tidak bias berjalan dengan baik, karena didalam pementasan memerlukan banyak orang, sehingga bisa berjalan dengan baik. Itulah nilai sosial di dalam pementasan, dan sebelum dilakukan pementasan. Pada saat awal persiapan mencerminkan aspek kekerabatan (persemetonan) dalam upaya merekatkan intregrasi antara seluruh seke barong, yang dimaksud disini adalah bagaimana didalam persiapan, pementasan dan akhir pementasan mempunyai rasa kebersamaan (solidaritas), hal ini bisa dilihat dari proses pembuatan sarana upakara. Setiap seke saling bekerja sama dalam pembuatan sarana upakara, seperti banten petangi, segeh agung, pejati dan banten kalangan, ini dilakukan bergiliran dengan rasa tulus iklas, dismping itu mempersiapkan ihasan panggung, misalnya seperti membikin penjor, mempersiapkan tiket, membersihkan sampah di areal pementasan dan sebagainya. Didalam mempersiapkan sarana dan prasarana tidak ada satupun seke barong yang diam cumacuma, semua seke barong ikut berpatisipasi 
didalam proses persiapan maupun pembuatan ihasan panggung, karea seke memahami dan menyadari bahwa ia adalah sebagai mahluk yang sosial tidak lepas dari gotong royong, dan seke memahami konsep tatwa masi bahwa kamu adalah aku dan aku adalah kamu, inilah yang terjadi sehingga sangat kuat nilai sosial masyarakat didalam pementasan tari barong ketet. Sosial masyarakat dimaksud disini adalah kekompakan antara seke barong. Tanpa adanya sosial masyarakat didalam pementasan ini pasti tidak bisa berjalan dengan baik, itulah nilai sosial di dalam pementasan tari barong ketet. Jadi dapat disimpulkan bahwa pementasan tari barong ketet merupakan, tindakan, sikap, tingkah laku dan perbuatan atas dasar suci (iklas) yang dilakukan bersama, Karena semua ini memegang peranan yang sangat penting didalam pementasan tari barong ketet. Jadi rasa persaudaraan dan kesatuan sangatlah penting kita bentuk, seperti yang dijelaskan dalam sloka Atharwaveda III. 30.4 sebagai berikut :

\section{Yena deva na viyanti no ca vidvisate mithah tat krnmo brahma vo grhe Samjnanam purunebhyah.}

Terjemahan :

"Wahai umat manusia, persatuanlah yang menyatukan semua para dewa. Aku memberikan yang sama kepadamu juga sehingga anda mampu menciptakan persatuan di antara anda" (Titib, 1996 : 347).

Bila di cermati isi dari sloka di atas, sebuah persatuan yang akan mendapat menyatukan kita semua. Persatuan adalah sumber kerukunan dan mengutamakan rasa persatuan, dengan rasa yang tulus ikhlas sebagai wujud persembahannya kehadapan Ida Sang Hyang Widhi Wasa Tuhan Yang Maha Esa. Sosial masyarakat sangat penting untuk memudahkan proses berlangsungnya kegiatan pementasan.
Disamping itu untuk merekatkan suatu hubungan antara persemetonan, sehingga mencerminkan suatu hubungan yang harmonis dan menanamkan konsep tatwa masi, konsep Tri Kaya Parisudha, baik memiliki pola pikir yang baik, memeliki perkataan yang baik, maupun berprilaku yang baik dan benar, sehingga mencapai keharmonisaan, inilah tujuan yang diharapkan dan sosial masyarakat ini yang terdapat dalam pementasan tari barong ketet.

\section{PENUTUP}

Pada bab ini akan dikemukakan Kesimpulan dan Saran. Berikut ini akan diuraikan masing-masing hal tersebut.

\section{KESIMPULAN}

Tarian Barong menggambarkan "Kebajikan" dan Rangda yang maha dahsyat menggambarkan "Kebatilan". Tari Barong Ketet menceritrakan pertarungan antara kebaikan dan keburukan. Adapun nilai yang terdapat dalam pementasan tari Barong mengandung unsur nilai pendidikan estetis, religius dan sosial masyarakat, nilai estetis terlihat pada kehindahan Barong sedangan nilai religius terdapat pada saat pemangku memendak (Mohon Keselamatan) sedangkan nilai sosial masyarakat terlihat pada kekompaka saling bantu sehingga pementasan barong ketet bisa berjalan sesuai yang telah di harapakn.

\section{SARAN}

1) Kepada Sekaa Barong untuk tetap dapat menjaga kualitas pertrunjukannya.

2) Kepada pakar seniman Barong hendaknya dapat memproduksi calon-calon penari dan penabuh untuk dibina atau dilatih agar tidak mengalami kekurangan penari dan penabuh dan memiliki generasi yang baru dan andal. 


\section{DAFTAR PUSTAKA}

Artadi, I Ketut. 2004. Nilai Makna dan Martabat Kebudayaan, Denpasar:Sinay

Duija, I Nengah. 2006. Bahan Mata Kuliah "Teori-teori Sosial Budaya"IHDN Denpasar: Program Pasca Sarjana

Dibia, I.Wayan, 2003. Pesta Kesenian Bali: Sebuah Peristiwa ritual baru Dua Puluh Lima Tahun Pesta Kesenian Bali, Denpasar: Panitia Penyelenggara Pesta Kesenian Bali Ke XXIII

-------------------, 2011.Ilen-ilen Seni Pertunjukan Bali, Penerbit. Bali MangsiDenpasar

--------------, 2012. Geliat Seni Pertunjukan Bali, Penerbit Buku Arti

Koentjaraningrat, 2002. Pengantar Antropologi Pokok-pokok Etnografi II, Jakarta: Rineka Cipta

Muhammad, Abdulkadir. 2005. Ilmu Sosial Budaya Dasar. Bandung : PT. Citra Aditya Bakti

Triguna, I.B Yudha.2000. Teori Tentang Simbol. Denpasar: Widya Dharma.

Titib, I Made. 1996. Veda Sabda Suci Pedoman Praktis Kehidupan. Surabaya : Paramita

Yudabakti I Made dan Watra I Wayan. 2007. Filsafat Seni Sakral dalam Kebudayaan Bali: Penerbit Paramita Surabaya 